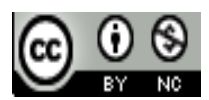

Jurnal Pendidikan Dasar Indonesia is licensed under

A Creative Commons Attribution-Non Commercial 4.0 International License

\title{
Efektivitas Model Pembelajaran STAD dan CIRC terhadap Peningkatan Keterampilan Kolaborasi Siswa Kelas V SD Gugus Joko Tingkir pada Mata Pelajaran Tematik
}

\author{
Junita $^{1)}$, Krisma Widi Wardani ${ }^{2)}$ \\ ${ }^{1)}$ Universitas Kristen Satya Wacana, Salatiga \\ E-mail: junita59723@gmail.com \\ ${ }^{2)}$ Universitas Kristen Satya Wacana, Salatiga \\ E-mail:krisma.widi@uksw.edu
}

\begin{abstract}
Abstrak. Penelitian ini bertujuan untuk menguji keefektifan model pembelajaran STAD dan CIRC terhadap keterampilan kolaborasi siswa kelas V SD Gugus Joko Tingkir Kota Salatiga. Aspek keterampilan kolaborasi yang dilihat dalam penelitian meliputi: kerja sama, tanggung jawab, kompromi, komunikasi, dan fleksibilitas siswa dalam kegiatan pembelajaran. Penelitian ini adalah penelitian eksperimen, jenis Quasi Eksperimental Research atau eksperimen semu dan tehnik yang digunakan untuk menentukan sampel adalah tehnik sampling purposive. Sample dalam penelitian ini SD Negeri Tingkir Lor 01 dan SD Negeri Tingkir Tengah 02. Subjek penelitian kelompok eksperimen 1 adalah 32 siswa kelas V SD Negeri Tingkir Lor 01 mendapat perlakuan model STAD. Sedangkan subjek penelitian kelompok eksperimen 2 yaitu 32 siswa Kelas V SD Negeri Tingkir Tengah 02 mendapat perlakuan model CIRC. Tehnik pengumpulan data penelitian menggunakan rubrik penilaian keterampilan kolaborasi dikembangkan oleh Triiling, selanjutnya data dianalisis dengan tehnik analisis statistik deskriptif. Berdasarkan uji prasyarat yang telah dilakukan, data berdistribusi normal sehingga analisis dilakukan dengan statistik parametrik berdasarkan uji independent sample t-test. Hasil penelitian menunjukkan hasil independent sample t-test diperoleh nilai Asymp. Sig.(2-tailed) $=0,000$ dimana nilai $<0,05$, yang artinya terdapat perbedaan keefektifan yang signifikan antara model STAD dan CIRC, maka $\mathrm{H}_{0}$ ditolak dan $\mathrm{H}_{\mathrm{a}}$ diterima. Adanya Perbedaan signifikan didukung dengan rerata kedua sampel penelitian, rerata kelompok eksperimen 1 yaitu 51,22 dan kelompok eksperimen 2 yaitu 54,31. Aspek yang memiliki kecenderungan nilai tinggi pada kelompok eksperimen 2 menyebar pada seluruh aspek baik kerja sama, tanggung jawab, kompromi maupun komunikasi. Artinya dengan menerapkan model CIRC lebih efektif dibanding STAD dalam meningkatkan keterampilan kolaborasi siswa.
\end{abstract}

Kata Kunci: STAD; CIR; Keterampilan Kolaborasi; Tematik

\section{PENDAHULUAN}

Pembelajaran tematik integratif adalah pembelajaran yang memuat beberapa muatan pembelajaran yang dijadikan satu tema yang disesuaikan dengan mata pelajaran yang akan dikembangkan dalam buku[1]. Pembelajaran tematik merupakan pembelajaran yang dikemas berdasarkan tema-tema yang kemudian dimuat dalam beberapa muatan pembelajaran [2]. Berdasarkan pendapatdiatas dapat disimpulkan bahwa pembelajaran tematik adalah pembelajaran yang menggunakan tema sebagai pemersatu kegiatan pembelajaran dalam muatan beberapa mata pelajaran. Pelaksanaanpembelajaran tematik membutuhkan landasan yang kuat berdasarkan pemikiranpemikiran yang mendalam serta sangat perlu diperhatikan pada saat merencanakan, melaksanakan dan menilai proses hasil pembelajaran yang dilaksanakan.Dalam pelaksanaan pembelajaran tematik guru diharapkan dapat mengoptimalkan potensi siswa dalam mengembangkan kemampuannya dikelas, yang tertuang dalam perencanaan, pelaksanaan kegiatan pembelajaran serta evaluasi proses belajar yang menunjukan bahwa siswa dapat mengembangkan berbagai potensi yang dimiliki. Pengembangan potensi dan keterampilan siswa di sekolah dalam pembelajaran merupakan salah satu kompetensi yang 


\section{JURNAL}

harus dipenuhi dan dilaksanakan dalam pembelajaran tematik. Dalam pelaksanaan pembelajaran tematik salah satu kompetensi yang harus dicapai siswa yaitu kompetensi keterampilan kolaborasi. Keterampilan kolaborasi adalah salah satu keterampilan yang mengajak siswa untuk aktif berkontribusi dalam bekerja sama dan melakukan interaksi pada saat pembelajaran sehingga pembelajaran akan lebih mudah dipahami.Keterampilan kolaborasi dapat diterapkan dalam pembelajaran yang mengajak siswa untuk aktif dan, komunikatif dalam bekerjasama, dan melakukan kompromi.

Untuk mengembangkan ketrampilan kolaborasi siswa, guru dapat menerapkan pembelajarandengan penerapan model pembelajaran kooperatif. Pembelajaran kooperatif adalah pembelajaran yang dapat membentuk siswa kedalam kelompok-kelompok kecil yang saling berinteraksi dan bekerja sama antar siswa [3].Dalam proses pembelajaran kooperatif learning terdapat interaksi yang lebih luas, dengan adanya interaksi antar siswa maka akan lebih leluasa untuk siswa mencari informasi dan mendiskusikannya bersama anggota kelompok. Keterampilan Kolaborasi merupakan salah satu bentuk interaksi sosial dalam bentuk kerja sama untuk mendorong siswa agar dapat bekerja sama dengan orang lain, dapat menerima orang lain, mampu menghadapi tantangan serta dapat berinteraksi yang dinyatakan oleh [1]. Kolaborasi merupakan suatu interaksi antar siswa yang bekerjasama dalam pemecahan suatu masalah dengan tanggung jawab setiap anggota kelompok melakukan komunikasi atau kompromi dalam kelompok untuk memecahkan masalah sebagai kepentingan bersama kelompok [4]. Berdasarkan pendapat diatas dapat disimpulkan bahawa keterampilan kolaborasi adalah suatu bentuk interaksi antar siswa dalam bekerja sama dengan kelompok sehingga dapat memberikan informasi dengan bertukar pendapat dan saling bekerja sama untuk kepentingan bersama. Adapun aspekaspek yang akan dilihat dari keterampilan kolaborasi adalah sebagai berikut: (1) kerjasama (2) tanggung jawab, (3) kompromi, (4) Komunikasi, (5) fleksibilitas. Model pembelajaran kooperatif yang berpotensi untuk meningkatkan kemampuan kolaborasi adalah model pembelajaran STAD, CIRC, GI, TGT, NHT dan Jigsaw.

Model pembelajaran STAD (Student Teams Achievement Division) dan model CIRC (Cooperative Integrated Reading and Composition) menarik untuk diteliti lebih lanjut sebab keduanya memiliki karakteristik sintak yang berbeda dalam pelaksanaannya, namun terdapat persamaan yaitu pembelajaran lebih menekankan pada aktifitas siswa untuk berkolaborasi atau bekerja sama dalam kelompok. Model pembelajaran STADmerupakan model pembelajaran yang memberikan peluang kepada siswa dalam bekerja sama untuk saling bertukar pikiran atau bertukar pendapat dalam memecahkan suatu masalah untuk mencapai tujuan bersama kelompok dalam[5]. Model STAD merupakan model yang membentuk siswa kedalam kelompok-kelompok kecil yang dibentuk secara heterogen berdasarkan jenis kelamin, suku, agama dan kemampuan akademik.Model CIRC merupakan model pembelajaran yang membentuk siswa kedalam kelompok dengan bertanggung jawab terhadap tugas kelompok dalam mencapai tujuan bersama anggota kelompok [6]. Model CIRC merupakan model yang membentuk siswa kedalam kelompok yang bertanggung jawab dalam membahas topik yang diberikandalam referensi [5]. Model CIRC merupakan model yang membentuk siswa kedalam kelompok dengan membahasbersama anggota kelompok tentang topik yang diberikan untuk mencapai tujuan bersama kelompok.

Kedua model pembelajaran tersebut memiliki kesamaan untuk meningkatkan keterampilan kolaborasi dengan tahapan pembelajaran yang berbeda. Hasil penelitian yang telah dikalakukan oleh peneliti terdahulu menunjukan kedua model ini sama-sama efektif untuk meningkatkan ketrampilan kolaborasi siswa. Berikut hasil penelitian terdahulu yang membuktikan bahwa model STAD dan CIRC berhasil. Penelitian yang dilakukan [7] yang melakukan penelitian eksperimen penerapan model kooperatif tipe STAD dalam pembelajaran tentang masalah sosial kelas IV SD, ini membuktikan bahwa model pembelajaran STAD dapat meningkatkan kemampuan berkolaborasi siswa dengan bekerja sama antar anggota kelompok yang heterogen. Berbeda dengan penelitian yang dilakukan oleh [8] yang melakukanpenelitian dengan judul pelaksanaan pembelajaranCIRC dalam meningkatkan kolaborasi siswa kelas III SD Kampung Anyar Kecamatan Bulelang, Kabupaten Bulelang dengan jumlah 14 siswa . Dalam penelitian ini membuktikan bahwa model CIRC dapat meningkatkan kolaborasi kerja sama antar siswa dalam mengembangkan pengetahuannya dengan saling bertukar pendapat. Hal ini menimbulkan keragu-raguan dari peneliti untuk mengujicobakan kedua model dalam penelitian eksperimen untuk membuktikan model mana yang paling ampuh dalam meningkatkan keterampilan kolaborasi siswa.

\section{KAJIAN PUSTAKA}

\section{Pembelajaran Tematik}

Berdasarkan implementasinya pembelajaran tematik lebih menekankan pada keterlibatan siswa dalam proses pembelajaran. Melalui pembelajaran tematik siswa mendapat pengalaman langsung dan terlatih untuk menemukan sendiri berbagai pengetahuan. Pembelajaran tematik adalah pembelajaran yang mengambil beberapa pokok bahasan atau tema dalam muatan pembelajaran yang menggabungkan beberapa materi pembelajaran menjadi satu tema yang kemudian dibuat jaring-jaring yang disederhanakan kedalam subtema-subtemasebagaimana pernyataan yang diperkuat dari referensi [9]. Pembelajaran tematik merupakan strategi pembelajaran yang diterapkan dalam pembelajaran yang dirancang berdasarkan tema-tema tertentu untuk mempermudah proses pembelajaran bagi siswa dikelas pernyataan referensi [10]. Oleh karena itu pembelajaran tematik merupakan pembelajaran yang terdiri dari tema tertentu yang kemudian tema yang dimuat dipecahkan atau dibagi kedalam subtema-subtema tertentu yang terdiri dari beberapa muatan pembelajaran. Model 


\section{JURNAL}

pembelajaran tematik menekankan pada siswa untuk terlibat langsung dalam proses pembelajaran sehingga memermudah siswa memahami materi yang disampaikan. Berdasarkan pelaksanaannya pembelajaran tematik memiliki karakteristik (1) Berpusat pada siswa, (2) Memberikan pengalaman langsung pada siswa, (3) Pemisahan mata pelajaran tidak begitu jelas, (4) Menyajikan konsep dari berbagai mata pelajaran, (5) Bersifat fleksibel, (6) Sesuai dengan minat dan kebutuhan siswa, (7) Menggunakan prinsip belajar sambil bermain dan menyengangkan. Dalam penerapannya pembelajaran tematik memiliki beberapa keunggulan diantaranya ialah: (1) pengalaman dan kegiatan belajar pada peserta didik sangat relevan, (2) kegiatan-kegiatan pembelajaran yang dipilih bagi peserta didik sesuai minat dan kebutuhan peserta didik, (3) kegiatan belajar yang lebih bermakna, sehingga peserta didik dapat ikut berpartisipasi dan mendapat pengalaman langsung, (4) dalam penerapannya sangat membantu peserta didik dalam mengembangkan keterampilan berpikir, (5) dalam menyajikan kegiatan pembelajaran dilakukan sesuai dengan permasalahan yang sering ditemui oleh peserta didik dari lingkungan seharihari, (6) dapat mengembangkan keterampilan sosial peserta didik seperti dapat bekerja sama, saling toleransi, berkomunikasi, dan selalu tanggap dalam gagasan orang lain. Dalam pelaksanaannya pembelajaran tematik siswa merupakan faktor yang utama keberhasilan pembelajaran yang dilaksanakan.

\section{Model Pembelajaran STAD (Student Teams Achievement Division)}

Model STAD merupakan model pembelajaran yang membentuk siswa kedalam kelompok-kelompok secara heterogen yang terdiri dari jenis kelamin, tingkat kemampuan prestasi dalam kelas, agama serta suku yang berbeda referensi buku dari [6]. Model pembelajaran STAD ialah model pembelajaran yang membentuk siswa dalam kelompok yang saling bekerja sama yang dalam pelaksanaan pembelajaran. Siswa diharuskan presentasi hasil yang dikerjakan bersama kelompok, kerja tim dalam kelompok, kuis dilaksanakan untuk menguji hasil kerja sama kelompok, skor serta rekognisi dalam pelaksanaannya dilaksanakan untuk melihat bahwa model pembelajaran $S T A D$ dapat memberikan pengaruh dalam meningkatkan kemampun kolaborasi setiap siswa dalam setiap kelompok.

Komponen-komponen dari model pembelajaran STAD dibagi kedalam fase-fase berdasarkan dalam buku [1]. Diantaranya adalah sebagai berikut: 1) Penyampaian tujuan dan motivasi, 2) Pembentukan kelompok secara heterogen, 3) Kegiatan kerja tim, 4) Kuis/Evaluasi, 5) Rekognisi/Reward. Adapun Karakteristik kelebihan model pembelajaran STAD [11] adalah sebagai berikut: (1) Peserta didik saling bekerja sama dan bertanggung jawab untuk memperoleh keberhasilan dalam kerja sama kelompok, (2) Model pembelajaran STAD membantu peserta didik untuk saling membantu dan saling memotivasi antar sesama dalam mencapai keterampilan dan keberhasilan dalam pembelajaran, (3) Setiap kelompok dapat bekerja sama dengan saling bertukar pendapat dan memberikan informasi dengan saling membantu untuk mencapai keberhasilan dalam pembelajaran, (4) Setiap kelompok saling memberikan dukungan kepada sesama dengan saling memberikan perhatian, bertukar pendapat serta saling memberikan dorongan untuk mencapai keberhasilan pembelajaran yang diharapkan. Dalam penerapannya model $S T A D$ memiliki beberapa unsur yakni: Unsur 1 Sintaks merupakan pedoman atau panduan yang mengarahkan pada langkah-langkah atau tahap-tahap pada model pembelajaran.

Unsur 2 Prinsip reaksi Dalam model pembelajaran STAD guru sebagai fasilitator atau yang memberikan arahan kepada siswa agar tujuan pembelajaran dapat dicapai. Dalam penerapan model pembelajaran STAD guru hanya memberikan arahan kepada siswa dalam menerapkan kerja sama antar kelompok dan kemudian siswa membentuk kelompok yang heterogen (beragam) untuk mencari informasi sesuai topik yang telah ditentukan.

Unsur 3 Sistem sosial Sistem sosial merupakan hubungan atau kerja sama antar guru dan siswa pada proses pembelajaran. Dalam menggunakan model pembelajaran STAD kegiatan pembelajaran berorientasi pada kerja sama tim antar siswa dalam kelompok.

Unsur 4 Sistem pendukung atau alat yang dibutuhkan, Dalam penerapannya model pembelajaran STAD sistem pendukung dari kondisi serta sarana dan prasarana penerapan pembelajaran tematik seperti rencana pelaksanaan pembelajaran (RPP), lembar kerja siswa, lembar evaluasi siswa, lembar analisis nilai siswa, serta papan tulis, LCD, dan menciptakan ruang kelas yang nyaman merupakan sistem pendukung dalam penerapan STAD.

Unsur 5 Dampak instruksional dan dampak pengiring, Dampak Instruksional adalah dampak dari hasil pembelajaran langsung yang dicapai oleh siswa dari materi pembelajaran yang sedang dilaksanakan dalam pembelajaran di kelas. Sedangkan dampak pengiring ialah sebagai iringan atau sampingan dari hasil pembelajaran langsung.

\section{Model Pembelajaran CIRC (Cooperative Integrated Reading And Composition)}

Pembelajaran CIRC merupakan penerapan pelaksanaan pembelajaran yang mengarahkan untuk setiap siswa dalam kelompok saling mengeluarkan ide-ide atau pendapat dengan bekerja sama untuk memahami suatu konsep dan menyelesaikan tugas. Model CIRC merupakan model pembelajaran kelompok yang menekankan pembelajaran membaca, menulis, dan tata bahasa siswa dalam membahas topik yang diberikan pada kelompokdalam referensi buku [1]. Model pembelajaran CIRC dikembangkan dalam buku [5]. Model pembelajaran CIRC diterapkan untuk mengetahui tingkat kemampuan pada siswa dalam membaca, menulis, dan tata bahasa 


\section{JURNAL}

melalui pengelompokan yang heterogen (heterogeneous grouping). Dalam penerapannya model CIRC menempatkan siswa pada kelompok-kelompok secara heterogen. Pada kegiatan pembelajaran penerapan model CIRC siswa mengikuti instruksi guru tentang keterampilan membaca, menulis dan kemudian mengikuti praktik yang selanjutnya mengikuti panduan pada saat akan diadakan kuis. Pada saat siswa bekerja sama dan dapat membaca, menulis setiap kelompok akan diberikan penghargaan (reward) yang pada saat kegiatan pembelajaran anggota kelompok mampu menunjukan kemampuan yang meningkat dalam aktivitas membaca dan menulis.

\section{Kajian Hasil Penelitian Yang Relevan}

Sejalan dengan penelitian yang dilakukan pada referensi [12] Penelitian ini dilakukan pada siswa kelas IV SD Gugus Merbabu. Berdasarkan hasil analisis data yang dilakukan penelitian ini menunjukan bahwa penerapan model pembelajaran STAD yang diterapkan dalam pembelajaran matematika terbukti bahwadalam pelaksanaannya dapat meningkatkan keterampilan berkolaborasi siswadengan saling bekerja sama antar siswa.

Penelitian yang dilakukan [13] penelitian yang dilakukan pada siswa kelas V SD Berugenjang Undaan Kudus. Dalam penelitian ini rancangan penelitan tindakan kelas kolaborasi dilaksanakan dalam dua siklus yang meliputi tahap pelaksanaan, perencanaan tindakan, pengamatan serta refleksi. Dari hasil penelitian pelaksanaan model STAD dapat meningkatkan kemampuan bekerja sama siswa dibuktikan siklus 1 dengan nilai rata-rata 74,5\% dan siklus 2 yang mengalamai peningkatan dengan nilai rata-rata $85,5 \%$. Dari hasil penelitian dapat disimpulkan bahwa penerapan model STAD dapat meningkatkan kemampuan bekerja sama siswa.

Penelitian yang dilakukan berdasarkan referensi [14]. Penelitian ini dilakukan pada siswa kelas V SD Negeri Cincenang yang terdiri dua kelas pararel yang terbagi 30 siswa dari kelas VA dan sebanyak 30 siswa dari kelas VB. Penelitian ini merupakan penelitian eksperimen yang terbagi dalam dua siklus pembelajaran dengan perlakuan yang berbeda yakni kelompok eksperimen dan kelompok kontrol. Berdasarkan hasil pengolahan data yang dilakukan pada kelompok eksperimen menunjukan hasil pengolahan rata-rata nilai prtetes 37,73 dan nilai posttest 65,85 sedangkan nilai rata-rata pretes kelompok kontrol 45,13 dan nilai rata-rata posttest 57,33. Dalam penelitian ini membuktikan bahwa penerapan model pembelajaran kooperatif tipe CIRC dalam pelaksanaannya mengalami peningkatan sehingga disimpulkanmodel CIRC dapat meningkatkan kemampuan berkolaborasi atau bekerja sama antarsiswa.

Berdasarkan hasil penelitian dan uraian di atas diketahui bahwa Model STAD dan Model CIRC samasama dapat meningkatkan ketrampilan kolaborasi yang lebih menekankan pada aspek kerja sama siswa baik yang dilakukan dalam penelitian eksperimen maupun penelitian tindakan kelas.

\section{METODE PENELITIAN}

Penelitian ini menggunakan jenis penelitian Quasi Eksperimental Research atau eksperimen semu. Eksperimen semu merupakan suatu penelitian yang mendekati percobaan yang sebenarnya, namun dalam penelitian ini percobaannya tidak dapat mengontrol variabel yang ada didalam penelitiannya [15]. Penelitian ini dilakukan di SD Gugus Joko Tingkir, Kecamatan Tingkir,Kota Salatiga. Tehnik penentuan sampel dalam penelitian ini menggunakan tehnik sampling purposive. Tehnik sampling purposive merupakan pemilihan pada sekelompok subjek dalam penelitian yang mempunyai kriteria-kriteria dan ciri-ciri yang sama berdasararkan letak pada gugus yang sama, serta memiliki karakteristik yang sama [16]. Tujuan tehnik penentuan sampel dengan sampling purposive adalah untuk mengetahui sampel yang dipilih apakah memenuhi kriteria dalam penelitian yang akan dilakukan. Adapun sampel penelitian ini meliputi siswa kelas V SD Negeri Tingkir Lor 01 yang berjumlah 32 siswa sebagai siswa eksperimen 1 model STAD dan Siswa kelas V SD Negeri Tingkir Tengah 02 yang berjumlah 32 siswa sebagai siswa eksperimen 2 model CIRC. Pengumpulan data pada penelitian ini menggunakan tehnik analisis statistik lembar observasi keterampilan kolaborasi siswa. Dengan instrumen keterampilan kolaborasi observasi terdapat 10 pernyataan yang valid pada eksperimen 1 model STADdengan angka reliabilitas cronbach's alpha 0,639 lebih besar dari koefisien $r$ tabel dengan $\mathrm{N}=32=0,349$ sehingga dapat disimpulkan instrumen berada pada kategori valid. Sedangkan pada kelompok eksperimen 2 instrumen keterampilan kolaborasi dengan angka reliabilitas cronbach's alpha 0,542 lebih besar dari koefisien $\mathrm{r}$ tabel dengan $\mathrm{N}=32=0,349$ sehingga disimpulkan instrumen berada pada kategori valid. Analisis data ini dilakukan dengan tehnik deskriptif dan tehnik statistik berdasarkan referensi [14]. Dilakukan uji prasyarat eksperimen diantaranya 1) Uji normalitas data, 2) Uji homogenitas.

Selanjutnya jika data memenuhi syarat normal dengan signifikansi $>0,05$ dan homogen jika signifikansi >0,05 maka pengolahan data dilanjutkan dengan uji beda rataratadan uji hipotesis untuk menentukan ada atau tidaknya perbedaan keefektifan yang signifikan pada model STAD dan CIRC terhadap keterampilan kolaborasi siswa kelas $\mathrm{V}$ dalam pembelajaran tematik.

\section{HASIL DAN PEMBAHASAN}

\section{Uji Prasyarat}

Untuk mengetahui data dari kedua model kelompok eksperimen 1 dan kelompok eksperimen 2 berdistribusi normal atau tidak, yang dilihat dari keterampilan kolaborasi maka digunakan rubrik penilaian keterampilan kolaborasi untuk mengukur kemampuan kerja samasiswa dalam pelaksanaan pembelajaran. Adapun rubrik penilaian keterampilan kolaborasi siswa dalam lembar observasi yang dinilai mencakup lima aspek yaitu kerja sama, tanggung jawab, kompromi, komunikasi dan fleksibilitas 
dalam kegiatan pembelajaran siswa. Dalam pelaksanaannya penilaian aspek kerja sama, tanggung jawab, kompromi, komunikasi dan fleksibilitas adalah dengan keterangan rubrik penilaian keterampilan kolaborasi menggunakan skala pengukuran skala likert dalam buku [17]. Skala likert yang yang dinilai berupa pernyataan frekuensi (selalu, sering, jarang dan tidak pernah). Dengan keterangan siswa yang mendapat skor 1 adalah siswa yang tidak pernah ikut berpartisipasi dalam kelompok, skor 2 siswa yang mendapat skor jika jarang memberikan ide atau pendapat, skor 3 siswa yang dalam kelompok sering menyampaikan ide, dan skor 4 adalah siswa yang selalu menyampaikan ide serta pendapatnya dan selalu ikut serta dalam kelompok.

Untuk mengetahui data berdistribusi normal atau tidak maka digunakan uji normalitas pada data. Uji normalitas data adalah uji yang dilakukan untuk mengetahui data berdistribusi normal atau tidakpernyataan dalam [15]. Pengujian normalitas data dilakukan dengan uji one-Sample Kolmogorov-Smirnov Test dengan bantuan SPSS 23 for windows. Dasar pengambilan keputusan data berdistribusi normal apabila nilai signifikansi probabilitasnya adalah lebih dari $>0,05$ dan data berdistribusi tidak normal adalah apabila nilai signifikansi probabilitas kurang dari $<0,05$.

Berdasarkan persyaratan uji normalitas maka dalam analisis data ini digunakan nilai hasil rubrik penilaian siswa yang diuji menggunakan SPSS 23 for window. Uji normalitas dilakukan adalah untuk mengetahui apakah data dari rubrik penilaian keterampilan kolaborasi yang mendapat perlakuan sesuai model pembelajaran yang diterapkan dalam kelas berdistribusi normal atau tidak.

Berdasarkan hasil uji normalitas rubrik penilaian keterampilan kolaborasi siswa untuk kelas eksperimen 1 diperoleh Asymp. Sig. (2-tailed) dengan nilai 0,200 dan eksperimen 2diperoleh nilai yang dilihat dari Asymp. Sig (2- tailed) 0,200. Berdasar nilai signifikansi Asymp. Sig (2tailed) berturut-turut dari kelompok eksperimen 1 dan kelompok eksperimen 2 adalah 0,200; 0,200 sehingga dapat dikatakan data berdistribusi normal karena nilai signifikansinya $>0,05$.

Berdasarkan uji homogenitas melalui Test of Homogeneity of Variancesdengan bantuan SPSS 23 for Windows, diperoleh nilai signifikansi rubrik penilaian keterampilan kolaborasimodel STAD dan CIRC pada kelompok eksperimen 1 dan kelompok eksperimen 2 0,612. Uji homogenitas digunakan untuk mengetahui apakah dua atau lebih kelompok data sampel berasal dari populasi yang memiliki variansi yang sama atau tidak. Kedua kelompok eksperimen 1 dan kelompok eksperimen 2 homogen dengan ketentuan nilai signifikansi probabilitas $>0,05$. Karena nilai signifikansi dari rubrik penilaian keterampilan kolaborasi antara kelompok eksperimen 1 dan kelompok eksperimen 2 adalah 0,612>0,05, maka dapat disimpulkan bahwa data yang digunakan dalam penelitian adalah homogen.

\section{Uji Hipotesis}

Setelah uji prasyarat telah terpenuhi dilakukan uji beda rata-rata pada tahap rubrik penilaian keterampilan kolaborasi siswa antara kelompok eksperimen 1 dan kelompok eksperimen 2. Uji beda dilakukan dengan Independent Samples Test menggunakan SPSS 23 for Windows dengan ketentuan apabila nilai Asymp. Sig (2tailed) kurang dari 0,05 maka tidak terdapat perbedaan, namun jika nilai Asymp. Sig (2- tailed) > 0,05 maka terdapat perbedaan rata-rata nilai signifikansi.

Hipotesis yang diuji dalam penelitian ini dirumuskan sebagai berikut:

$\mathrm{H}_{0}: \mu_{1}=\mu_{2}$ : Tidak terdapat perbedaan yang signifikan antara penggunaan model STAD dan CIRC terhadap peningkatan keterampilan kolaborasi siswa dalam pembelajaran tematik siswa kelas $\mathrm{V}$

$\mathrm{H}_{\mathrm{a}:} \mu_{1} \neq \mu_{2:} \quad$ Terdapat perbedaan yang signifikan antara penggunaan model STAD dan CIRC terhadap peningkatan keterampilan kolaborasi siswa dalam pembelajaran tematik siswa kelas $\mathrm{V}$

Pengambilan keputusan hasil penelitian ini dilakukan dengan uji hipotesis berdasarkan tes yang telah dilakukan. Apabila nilai Asymp. Sig (2- tailed) $<0,05$ maka $\mathrm{H}_{0}$ ditolak dan $\mathrm{H}_{\mathrm{a}}$ diterima. Sebaliknya apabila nilai Asymp. Sig (2- tailed) > 0,05 maka $\mathrm{H}_{0}$ diterima dan $\mathrm{H}_{\mathrm{a}}$ ditolak.

Adapun hasil uji beda rata-rata 2 kelompok eksperimen 1 dan eksperimen 2 adalah sebagai berikut.

Tabel I

Hasil Uji Beda Rata-Rata

Independent Samples Test

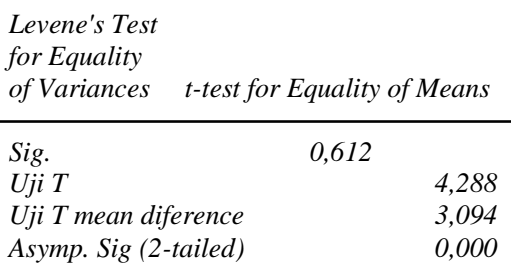

Uji beda dilakukan dengan Independent Samples Test menggunakan SPSS 23 for Windows dengan ketentuan apabila nilai Asymp. Sig (2- tailed) kurang dari<0,05 maka tidak terdapat perbedaan, namun jika nilai Asymp. Sig (2tailed) $>0,05$ maka terdapat perbedaan rata-rata nilai signifikansi. Berdasarkan uji beda rata-rata rubrik penilaian keterampilan kolaborasi siswa antara kelompok eksperimen 1 dan eksperimen 2diperoleh nilai signifikansi/probabilitas Asymp. Sig (2- tailed) adalah 0,000 $<0,005$ maka tidak signifikan atau $\mathrm{H}_{0}$ ditolak. Uji $\mathrm{t}$ dilihat dari hasil t-test for Equality of Meansadalah sebesar 4,228> 0,05. Perbedaan rata-rata dari kelompok mean diference adalah sebesar3,094.

Berdasarkan hasil kriteria pengajuan hipotesis untuk membuktikan hasil terdapat perbedaan antara rubrik penilaian keterampilan kolaborasi kelompok eksperimen 1 dan kelompok eksperimen 2 digunakan uji statistik parametrik independent sample t-test menggunakan SPSS 


\section{JURNAL}

23 for windows dengan cara menghitung nilai rata-rata rubrik penilaian keterampilan kolaborasi dari kelompok eksperimen 1 yang menggunakan model STAD dan kelompok eksperimen 2 yang menggunakan model CIRC.

Berdasarkan hasil pembuktian pada t-test dari hasil independent sample t-testnilai signifikansi pada Sig (2tailed) menunjukan 0,000 $<0,05$ sehingga $\mathrm{H}_{0}$ ditolak dan $\mathrm{H}_{\mathrm{a}}$ diterima maka dari itu uji hipotesis tersebut dapat disimpulkan bahwa terdapat adanya perbedaan yang signifikan dari efektifitas model pembelajaran STAD dan CIRC terhadap keterampilan kolaborasi siswa. Model pembelajaran STAD dengan CIRC dapat meningkatkan keterampilan kolaborasi siswa. Keberhasilan penelitian ini dapat didukung dengan dilihat dari hasil rubrik penilaian keterampilan kolaborasi siswa yang dilakukan pada model STAD dan model CIRC.

Berdasarkan hasil rubrik penilaian antara kelompok eksperimen 1 dan eksperimen 2 selisih dengan perbandingan nilai bahwa nilai rata-rata model CIRC lebih tinggi 3,09 dari model STAD. Model CIRC dengan nilai rata-rata dari 32 siswa adalah sebesar 54,31 dan model STAD dengan nilai rata-rata 51,22 dari 32 siswa. Berdasarkan hasil pengolahan data kelompok eksperimen 2 sebagai perlakuan model pembelajaran CIRC lebih lebih tinggi dibandingkan menggunakan model STAD sehingga dapat dikatakan bahwa dalam penelitian ini model CIRC lebih efektif untuk meningkatkan keterampilan kolaborasi siswa di Gugus Joko Tingkir.

Kefektifan model pembelajaran CIRC dibandingkan model STAD yang berbeda secara signifikan. Penelitian yang dilakukan [18] yang menyatakan bahwa model CIRC berjalan dengan lancar sesuai dengan sintak dan rencana pembelajaran yang dilaksanakan dalam penelitian. Penelitian yang dilakukan [19] yang menyatakan model pembelajaran CIRC lebih efektif untuk meningkatkan keterampilan pembelajaran kerja sama siswa daripada menggunakan model STAD dengan Jigsaw. Penelitian yang dilakukan [20] yang menyatakan bahwa keterampilan menulis secara keseluruhan lebih efektif menggunakan model pembelajaran CIRC. Pembelajaran CIRC adalah salah satu model pembelajaran yang dapat membantu siswa dalam mencapai tujuan pembelajaran. Jadi berdasarkan pendapat penelitian terdahulu dan penelitian yang dilakukan bahwa model pembelajaran CIRC lebih efektif dalam penerapan pembelajaran kolaborasi siswa. Penelitian pada referensi [21] penelitian yang dilaksanakan dalam dua siklus yang terjadi peningkatan yang keterampilan kolaborasi dari 61,81 mengalami peningkatan pada siklus 1 67,27 dan lebih meningkat pada nilai siklus 2 dengan nilai 83,18 . Berdasarkan hasil penelitian dapat meningkatkan keterampilan kolaborasi siswa.

\section{KESIMPULAN DAN SARAN}

\section{Kesimpulan}

Berdasarkan pembahasan dapat disimpulkan bahwa terdapat perbedaan yang signifikan antara penerapan model
STAD dan CIRC terhadap peningkatan keterampilan kolaborasi siswa. Perbedaan yang signifikan yang dilihat dari pengujian hipotesis yang dari hasil ujiindependent sample t-test dengan nilai signifikansi Asymp. Sig (2tailed) $0,000<0,05$ maka $\mathrm{H}_{0}$ ditolak dan $\mathrm{H}_{\mathrm{a}}$ diterima. Berdasarkan hasil uji hipotesis membuktikan terdapat perbedaan keefektifan antara model STAD dan Model CIRC. keefektifen dari dua model pembelajaran STAD dan $C I R C$ juga dilihat dari hasil uji rata-rata nilai antara dua model. Berdasarkan hasil uji rerata daridua model antara kelompok eksperimen 1 yang mendapat perlakuan model $S T A D$ dan kelompok eksperimen 2 yang mendapat perlakuan model CIRC. Kelompok eksperimen 1 memperoleh nilai rata-rata 51,22 dan untuk kelompok eksperimen 2 mendapat nilai rata-rata 54,31. Berdasarkan hasil nilai rerata membuktikan bahwa pelaksanaan model CIRC dalam meningkatkan keterampilan kolaborasi siswa lebih efektif dibanding pelaksanaan model STAD.

\section{Saran}

Saran bagi bagi guru yang akan memfokuskan meningkatkan aspek kerja sama, tanggung jawab, kompromi, komunikasi, dan fleksibilitas siswa dalam kegiatan pembelajaran atau dalam hal ini ketrampilan kolaborasi maka dapat menggunakan model pembelajaran CIRC.

\section{DAFTAR PUSTAKA}

[1] Darmo, W. (2017). Penerapan Model STAD untuk meningkatkan Hasil Belajar Kelompok PKN Materi Organisasi Kelas V SD Berugenjang Kudus. Majalah Ilmiah Pendidikan Dasar, 175.

[2] Febriyanto, B. (2018). Efektifitas Model Pembelajaran CIRC dalam Keterampilan Menulis Paragraf Narasi Siswa di Sekolah. Jurnal of learning education adn counseling, 6 .

[3] Hamdani, dkk. (2019). Penerapan Model Pembelajaran Tematik Terpadu Kelas V untuk Peningkatan Keterampilan Kolaborasi . Jurnal Ilmiah Sekolah Dasar, Undiksha, 440447.

[4] Huda. (2013). Model-model Pengajaran dan Pembelajaran. Malang: Pustaka Pelajar.

[5] Junita. (2019). Upaya Pengembangan Potensi Belajar Siswa Kelas 5 Sekolah Dasar Kanisius Gendongan Salatiga menggunakan Cooperative Learning. Trihayu: Jurnal Pendidikan Ke-SD an, 709.

[6] Margono. (2004). Metodologi Penelitian Pendidikan. Jakarta: Rineka Cipta.

[7] Murtono. (2012). Pengaruh Model Pembelajaran Kooperatif CIRC, Jigsaw dan STAD terhadap Keterampilan Membaca ditinjau dari Kemampuan Logika Berbahasa. Kajian Linguistik dan Sastra. UMS, 194.

[8] Nurul, H. (2015). Pembelajaran Tematik Integratif di Sekolah Dasar. Radenintan, 35.

[9] Purnomo, dkk. (2018). Kefektifan Model Pembelajaran STAD dan CIRC ditinjau dari Hasil Belajar Matematika Siswa Kelas 4 SD. JKPM, 6.

[10] Rini, K. (2014). Analisis Kesiapan Guru Sekolah Dasar Dalam Mengeimplementasikan Pembelajaran Tematik Integratif Menyongsong Kurikulum 2013. Undiksha, 461. 
[11] Rochmatin, G. G. (2014). Penerapan Model Pembelajaran Kooperatif Tipe STAD meningkatkan Hasil Belajar Siswa dalam Pembelajaran IPS Kelas IV. JPGSD Universitas Negeri Surabaya, 5-6.

[12] Rusman, M. (2012). Belajar dan Pembelajaran Berbasis Komputer. Gerlong Tengah: Alfabeta, Bandung.

[13] Shalomo, S. (2012). The Hanbook of Cooperative Learning. Yogyakarta: Familia Grup Relasi Inti Media

[14] Slameto. (2015). Metodologi Penelitian dan Inovasi Pendidikan. Salatiga. Satya Wacana University Press.

[15 Sugiyono. (2012). Metode Penelitian Pendidikan Pendekatan Kuantitatif, Kualitaitf dan R\&D. Bandung: Alfabeta

[16] Slavin, Robert E. (2009). Cooperative Learning (Teori, Riset dan Praktik). Bandung: Nusa Media
[17] Slavin, Robert E. 2011. Cooperative Learning Teori, Riset dan Praktik. Bandung: Nusa Media.

[18] Suarta Komang, A. P. (2017). Pengaruh Penerapan Model Pembelajaran Kooperatif Tipe STAD terhadap Hasil Belajar Tehnik Dasar Passing Sepak Bola. e-Journal PJKR Universitas Pendidikan Ganesha, 7.

[19] Trilling, B. \& Fadel, C., 21st Century Skills: Learningfor life in Our Times, San Francisco. (2009). Jossey-Bass A Wiley Imprint).

[20] Wahyuni, S. (2018). Pengaruh Model Pembelajaran Kooperatif Tipe CIRC terhadap Keterampilan Menulis Cerpen Siswa Kelas X SMA Negeri 2 Sungai Penuh, Provinsi Jambi. UNES, Jurnal Of Education Scienties, 181.

[21] Wangid Nur Muhamad, M. A. (2014). Kesiapan Guru SD dalam Pelaksanaan Pembelajaran Tematik Integratif Pada Kurikulum 2013 Di DIY . Jurnal Edukasia UNY, 177. 